\title{
Investor Attention and Broad Market Index: Evidence From Indonesia Composite Index
}

\author{
*Olivia Tanaya ${ }^{1}$ Suyanto Suyanto ${ }^{2}$
}

\author{
${ }^{1}$ University of Surabaya, Surabaya, Indonesia \\ ${ }^{2}$ University of Surabaya, Surabaya, Indonesia \\ *Corresponding author. Email: oliviatanaya@staff.ubaya.ac.id
}

\begin{abstract}
This study examines the relationship between investor attention and the broad market index in the Indonesia Composite Index (IHSG). In today's digital world, the search engine becomes the most important tool in looking for information. Google dominated the market share with $91.38 \%$ of people use it. This number supports the use of Google to observe the behavior of the market. Instead of using it in specific assets or securities that can limit the scope of investors, this study is interested in using it in broad market index. Using Granger Causality Test and Vector Autoregression (VAR), we find that increasing attention can increase return and reduce market volatility. On the other hand, there is an indication that investors in Indonesia are typically risk-averse investors.
\end{abstract}

Keywords: investor attention, Google Trend, Google Search, broad market index.

\section{INTRODUCTION}

Ideally, in the capital market, firms can make the production-investment decision, and investors can choose investment products at any time with the assumption that their prices fully reflect all available information. This condition is called an "efficient market" (Fama 1970). However, in the real world, access to information is different for every investor. Since attention is a limited source (Kahneman 1973), investors only access information that is interesting for them. This, in turn, suggests that attention from investors should be related to the activities in the market (Padungsaksawasdi et al. 2019).

To measure investor attention, we use the data from Google with the consideration that the internet, especially search engines, becomes the most important tool in looking for information. Among search engine market share worldwide in January 2021, 91.86\% use Google (GlobalStats 2021). This number shows that Google is an appropriate tool to observe the behavior of the market. Google provides a platform to precisely count the number of searches, which is called Google Trend.

Using this platform, we can trace the number of people interested in certain subjects; for example, if we are interested in specific companies, we will look for information related to the companies and limit our attention and time to these companies. The relevance of Google Trend has been well documented, such as help to improve the prediction of youth unemployment (Fondeur \& Karamé 2013), gold price movement (Baur \& Dimpfl 2016), and stock trading activity (Kim et al. 2019).

Instead of using it in the specific asset or securities, this study investigates the relationship between investor attention and broad market index. Unlike specific securities that limit the scope of investors, the broad market index can cover a broad range of investors' interests. Investors are more likely to collect information related to the 
market than firm-specific information (Aouadi et al. 2013). In addition, while the other papers focus on the US stock market or another developed market, this paper focuses on the Indonesian stock market, which can help capture the condition in the developing market.

According to efficient market hypothesis theory, when new information is available in the market, investors can receive, analyze, and use the information for trading without limited resources such as attention, time, and processing resource. Hence, the security price immediately changes and drives rational trading (Padungsaksawasdi et al. 2019). However, investors only have limited attention that they can use to proceed with the information. Barber and Odean (2008) define attention-grabbing stock - the presence of stock in the news causes the stock to experience extreme return and high abnormal trading volume. Accordingly, stocks that receive more attention from investors are relatively more traded than stocks acquiring less attention.

On the other hand, the effect of return or volatility on investor attention is derived from risk-taking behaviour. In traditional behaviour theory, risk is associated with the term "uncertainty" (Highhouse \& Yüce 1996). A risk-averse investor is the tendency of decision-maker to prefer a sure thing to an uncertain outcome (high uncertainty). There must always be a positive risk premium to encourage risk-averse investors to hold the existing supply of stock instead of putting their money in the risk-free asset (Bodie et al. 2014).

\section{RESEARCH METHODS}

\subsection{Data and variable}

Google Trend is a website by Google Inc. that provides data to show how frequently a given search term is entered into Google Search over a given period term. Google provides a feature to filter the data such as the scope of region, period, categories of search queries, and web search. In this study, we use the keyword "IHSG" to capture Indonesia's market index and filter it by the scope of Indonesia. IHSG is a merger between Jakarta Stock Exchange and Surabaya Stock Exchange. The merger occurs effectively on 1 December 2007. Hence, our sample uses monthly data from December 2007 until January 2021. The data for IHSG is in Rupiah and taken from Yahoo Finance.

\subsection{Method and model}

For the first step, we begin our analysis by Granger Causality Test to investigate possible causal relationship between variables. After that, Vector Autoregression (VAR) is employed to analyse the sign and timing of Google Trend effect.

\subsection{Granger causality Test}

According to Granger (1969), Y grangercause $\mathrm{X}$ if $\mathrm{Y}$ contains information in the past term that can help to forecast the value of $X$. Feedback is said to occur when between two variable $\mathrm{Y}$ granger-cause $\mathrm{X}$ and $\mathrm{X}$ grangercause $Y$. Granger causality will be used to examine the relationship between Google Trend and IHSG.

\subsection{Vector autoregression (VAR)}

VAR is often suggested as alternative to large-scale simultaneous equations structural models. This paper uses bivariate VAR model to analyse sign and timing of one variable to another variable. Here is the model for bivariate VAR:

$X_{1 t}=a_{10}+a_{11} X_{1 t-1}+\cdots+a_{1 k} X_{1 t-k}+\beta_{11} X_{2 t-1}+\cdots+\beta_{1 k} X_{2 t-k}+\varepsilon_{1 t}(1)$
$X_{2 t}=a_{20}+a_{21} X_{2 t-1}+\cdots+a_{2 k} X_{2 t-k}+\beta_{21} X_{1 t-1}+\cdots+\beta_{2 k} X_{1 t-k}+\varepsilon_{2 t}(2)$

Where $X_{1 t}$ and $X_{2 t}$ are the variables which each of current value depend on different combinations of the previous $\mathrm{k}$ value of both variables. $\varepsilon_{1 \mathrm{t}}$ and $\varepsilon_{2 \mathrm{t}}$ are white nose error terms. 


\section{RESULTS AND DISCUSSIONS}

\subsection{Findings of granger causality test}

Following Vozlyublennaia (2014), this paper uses the lag 2, 4, 6 to test the causality between the variables. Table 1 contains the result of causality test between IHSG return and Google Trend. Based on the results, when 2 lags are included in the model. There is no-causality between IHSG return and Google Trend. When 4 lags are included, it reveals that IHSG return granger-cause Google Trend as the probability is 0.0587 . It means that the return of IHSG has an impact on Google Trend. On the other hand, attention does not have any impact on IHSG return.

Table 1. Granger Causality between IHSG return and Google Trend

\begin{tabular}{|c|c|c|c|c|}
\hline $\begin{array}{l}\mathrm{Lag} \\
(\mathrm{k})\end{array}$ & Null Hypothesis & F-stat. & Prob. & Decision \\
\hline \multirow{6}{*}{2} & IHSG return does not & & & \\
\hline & Granger Cause Google & & & \\
\hline & Trend & 1.3550 & 0.2611 & Accepted \\
\hline & Google Trend does not & & & \\
\hline & Granger Cause IHSG & & & \\
\hline & return & 0.8327 & 0.4369 & Accepted \\
\hline \multirow{6}{*}{4} & IHSG return does not & & & \\
\hline & Granger Cause Google & & & \\
\hline & Trend & 2.3310 & 0.0587 & Rejected \\
\hline & Google Trend does not & & & \\
\hline & Granger Cause IHSG & & & \\
\hline & return & 1.1291 & 0.3452 & Accepted \\
\hline \multirow{6}{*}{6} & IHSG return does not & & & \\
\hline & Granger Cause Google & & & \\
\hline & Trend & 1.7297 & 0.1185 & Accepted \\
\hline & Google Trend does not & & & \\
\hline & Granger Cause IHSG & & & \\
\hline & return & 1.7070 & 0.1238 & Accepted \\
\hline
\end{tabular}

The results of causality test between return volatility and Google Trend are reported in Table 2. When 2 lags are included, the causality is only found in one direction, that is, Google Trend has an impact on the volatility return of IHSG. When 4 lags are included, it shows an additional relationship. Causality runs between IHSG return volatility and Google Trend. Although it does not have any impact on the return, it can influence the volatility return. Increasing the lags to 6 lags reduces the significant levels for model 1 (IHSG return and Google Trend) and model 2 (IHSG return volatility and Google Trend), hence, it can be interpreted as the model may be over-specified in terms of the number of lags.

Table 2. Granger Causality between IHSG return volatility and Google Trend

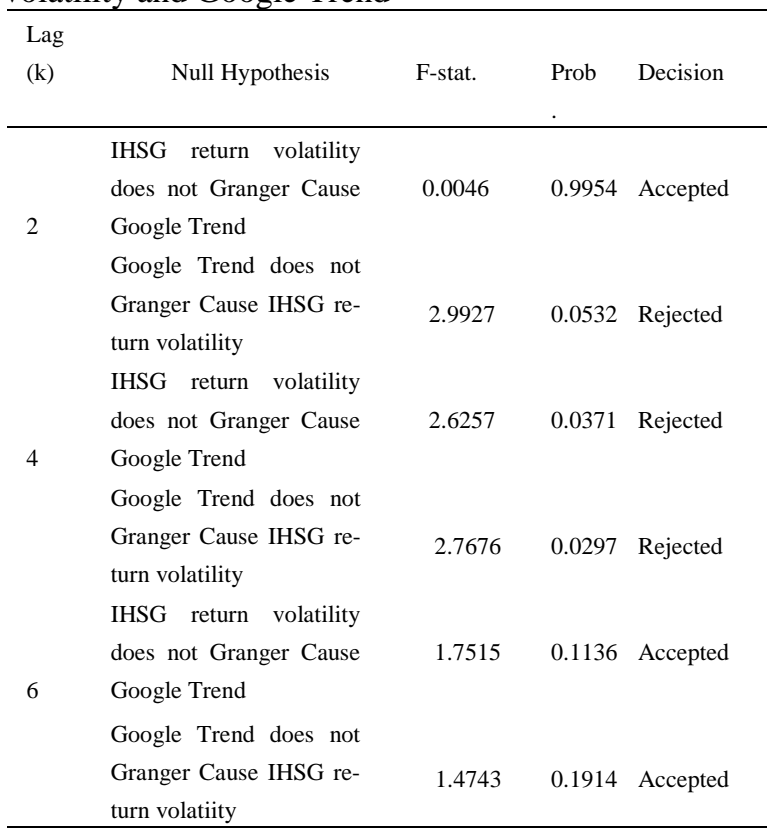

\subsection{Findings of vector autoregression (VAR)}

In this section, VAR is employed to determine the sign and timing between variables. Based on the results in Table 3, it can be seen that IHSG return and Google Trend have a causal positive significant effect. When a positive return occurs, it drives people to pay more attention to IHSG. On the other hand, when IHSG captures investor attention and searches intensively, it generates a positive return. This condition is in line with the attention hypothesis theory by Barber and Odean (2008). The probability of investors to invest stocks increases as more people pay attention to IHSG. Thus, it will cause higher price pressure and higher return.

As the significance level for both models is found in Lag 4, it can be concluded that the effects do not immediately occur. The 
delayed response is in line with Kim et al. (2019) that state Google Search is more related to future trading than current trading activity. Da et al. (2011) find a similar delayed response in their research, but the delayed response is within a few weeks. The long-delayed response in this study is probably due to information efficiency is lower in developing countries as the access to information is more complex and diverse (Tan \& Taş 2019).

Table 3. VAR between IHSG Return and Google Trend

\begin{tabular}{lll}
\hline & Google Trend & IHSG Return \\
\hline Intercept & 0.0093 & 0.0044 \\
& $(-0.0287)$ & $(-0.0047)$ \\
Google Trend (-1) & -0.4885 & -0.0081 \\
& $(0.0844)^{* * *}$ & $(-0.0137)$ \\
Google Trend (-2) & 0.2778 & 0.0107 \\
& $(0.0917)^{* * *}$ & $(-0.0149)$ \\
Google Trend (-3) & -0.1275 & 0.0065 \\
& $(-0.0918)$ & $(-0.0149)$ \\
Google Trend (-4) & -0.1675 & 0.0229 \\
& $(0.0797)^{* *}$ & $(0.0129)^{*}$ \\
IHSG Return (-1) & 0.6204 & 0.2927 \\
& $(-0.5300)$ & $(0.0858)^{* * *}$ \\
IHSG Return (-2) & -0.7215 & -0.0548 \\
& $(-0.5494)$ & $(-0.0890)$ \\
IHSG Return (-3) & 0.6314 & 0.1156 \\
& $(-0.5533)$ & $(-0.0896)$ \\
IHSG Return (-4) & 1.0111 & 0.0201 \\
R-squared & $(0.5302)^{*}$ & $(-0.0859)$ \\
\hline Note: & 0.2886 & 0.1196 \\
\hline
\end{tabular}

Note: * indicates the significance at the $10 \%$ level, ** indicates the significance at the $5 \%$ level, *** indicates the significance at the $1 \%$ level.

On the other hand, in Table 4, it reveals that IHSG return volatility and Google Trend has a negative relationship. When attention is high, people are learned better and become more certain about their investment. As consequence, it generates a low level of volatility (Andrei \& Hasler 2015, Aouadi et al. 2013). Unlike return, increase volatility can significantly reduce the attention of people. Based on the results, there is an indication that Indonesian investor is typically riskaverse investor. When there is a positive risk premium, more investors pay attention to IHSG. A risk-averse investor will reject investment with zero risk premium. Volatility commonly shows the risk of an asset. The more volatile the market, the higher the risk associated with the investment. This highrisk investment may cause risk-averse investors to penalize the possible expected rate of return. Hence, they avoid investing during this period.

Table 4. VAR between IHSG return volatility and Google Trend

\begin{tabular}{|c|c|c|}
\hline & Google Trend & IHSG Return Volatility \\
\hline \multirow[t]{2}{*}{ Intercept } & 0.0877 & 0.0231 \\
\hline & $(0.0577)^{*}$ & $(0.0059)^{* * *}$ \\
\hline \multirow[t]{2}{*}{ Google Trend (-1) } & 0.5097 & -0.0198 \\
\hline & $0.0879)^{* * *}$ & $(0.0103)^{*}$ \\
\hline \multirow[t]{2}{*}{ Google Trend (-2) } & -0.3069 & -0.0347 \\
\hline & $(0.0965)^{* *}$ & $(0.0113)^{* *}$ \\
\hline \multirow[t]{2}{*}{ Google Trend (-3) } & -0.1576 & -0.0183 \\
\hline & $(0.0979)$ & $(0.01115)$ \\
\hline \multirow[t]{2}{*}{ Google Trend (-4) } & -0.1283 & 0.0049 \\
\hline & $(0.0846)$ & $(0.0099)$ \\
\hline \multirow[t]{2}{*}{ IHSG Return Volatility(-1) } & -0.2781 & 0.3010 \\
\hline & $(0.7915)$ & $(0.0925)^{* * *}$ \\
\hline \multirow[t]{2}{*}{ IHSG Return Volatility(-2) } & 0.5596 & 0.1950 \\
\hline & $(0.8019)$ & $(0.0938)^{* *}$ \\
\hline \multirow[t]{2}{*}{ IHSG Return Volatility(-3) } & 0.3415 & -0.0456 \\
\hline & $(0.8106)$ & $(0.0948)$ \\
\hline \multirow[t]{2}{*}{ IHSG Return Volatility(-4) } & -2.4026 & 0.0157 \\
\hline & $(0.7575)^{* *}$ & $(0.0886)$ \\
\hline R-squared & 0.2941 & 0.1585 \\
\hline
\end{tabular}

Note: $*$ indicates the significance at the $10 \%$ level, $* *$ indicates the significance at the $5 \%$ level, *** indicates the significance at the $1 \%$ level.

\section{CONCLUSION}

The paper aims to investigate the relationship between Google Trend and broad market index in Indonesia (IHSG). Regarding IHSG's return, we show that when IHSG gains more attention, it tends to generate a 
positive return. Increase attentions tend to increase the probability of investors to invest, thus, it causes higher price pressure and higher return. On the other hand, increase attention makes investors learn better and reduce uncertainty. Hence, as attention increases, the market becomes less volatile. Last, we demonstrate that there is an indication that investors in Indonesia are typically risk-averse investors.

\section{REFERENCES}

Andrei, D. \& Hasler, M. 2015. Investor Attention and Stock Market Volatility. The Review of Financial Studies 28(1): 33-72.

Aouadi, A. Arouri, M. \& Teulon, F. 2013. Investor attention and stock market activity: Evidence from France. Economic Modeling 35: 674-681.

Barber, B.M. \& Odean, T. 2008. All that glitters: The effect of attention and news on the buying behavior of individual and institutional investors. Review of Financial Studies 21(2): 785-818.

Baur, D.G. \& Dimpfl, T. 2016. Googling gold and mining bad news. Resources Policy 50(0): 306311.

Bodie, Z. Kane, A. \& Marcus, A.J. 2014. Investments (10th). McGraw-Hill Education.

Da, Z. Engelberg, J. \& Gao, P. 2011. In Search of Attention. The Journal of Finance 66(5): 14611499.

Fama, E.F. 1970. Efficient Capital Markets: A Review of Theory and Empirical Work. The Journal of Finance 25(2): 383-417.

Fondeur, Y. \& Karamé, F. 2013. Can Google data help predict French youth unemployment? Economic Modeling 30(1): 117-125.

GlobalStats. 2021. Search Engine Market Share Worldwide.

Granger, C.W. 1969. Investigating causal relations by econometric models and cross-spectral methods. Econometrica Econometrica 37(3): 424438.

Highhouse, S. \& Yüce, P. 1996. Perspectives, perceptions, and risk-taking behavior. Organizational Behavior and Human Decision Processes 65(2): 159-167.

Kahneman, D. 1973. Attention and Effort. Englewood Cliffs: Princeton Hall.

Kim, N. Lučivjanská, K. Molnár, P. \& Villa, R. 2019. Google searches and stock market activity: Evidence from Norway. Finance Research Letters 28: 208-220.

Padungsaksawasdi, C. Treepongkaruna, S. \& Brooks, R. 2019. Investor Attention and Stock Market Activities: New Evidence from Panel
Data. International Journal of Financial Studies 7(2): 1-19.

Tan, S. D. \& Taş, O. 2019. Investor attention and stock returns: Evidence from Borsa Istanbul. Borsa Istanbul Review 19(2): 106-116.

Vozlyublennaia, N. 2014. Investor attention, index performance, and return predictability. Journal of Banking and Finance 41(1): 17-35. 